\title{
A comparison of woody browse selection by hand-raised, boma-adapted and wild black rhinoceros, Diceros bicornis, L. in Matusadona National Park, Zimbabwe
}

\author{
G. Matipano
}

Matipano, G. 2003. A comparison of woody browse selection by hand-raised, bomaadapted and wild black rhinoceros, Diceros bicornis, L. in Matusadona National Park, Zimbabwe. Koedoe 46(2): 83-96. Pretoria. ISSN 0075-6458.

Differences in woody browse selection between hand-raised (and subsequently released), boma-adapted and wild black rhinoceros, Diceros bicornis, L. were studied in Matusadona National Park between December 1999 and July 2000. Boma-adapted rhinoceros were animals that were subjected to hand-raising and were kept in bomas (enclosures) over night. The feeding behaviour was different between the three rhinoceros groups. All rhinoceros groups utilised and selected for a few browse species in common, at different preference levels in the same habitat types according to season. Wild rhinoceroses browsed most in Colophospermum-Terminalia-Combretum woodland in the wet season and in thicket in the dry season. Hand-raised rhinoceroses browsed most in Colophospermum-Terminalia-Combretum woodland and boma-adated rhinos in thickets in both the wet and the early dry seasons. Hand-raised and bomaadapted rhinos changed their habitats less for browse selection than wild rhinos. This can be ascribed to a relative restriction of home range in the hand-raised group and a herding effect for the boma-adapted animals. These situations might have accounted for differences in seasonal browse selection by the rhinoceros groups.

Key words: black rhino, hand-raised, browse selection.

G. Matipano, Matusadona National Park, Department of National Parks and Wildlife Management, P. Bag 2003, Kariba, Zimbabwe. Present address: National Unversity of Science and Technology, Department of Forest Resources and Wildlife Management, P.O. Box AC 939, Ascot, Bulawayo, Zimbabwe (gmatipano@nust.ac.zw).

\section{Introduction}

The black rhinoceros is predominantly a browser, concentrating on forbs and lowgrowing shrubs; most browsing (ca $60 \%$ ) takes place within a 2-m height zone from the ground (Owen-Smith 1988). Black rhinoceroses eat woody plants, forbs, creepers and succulents. However, grass and forbs constitute only a very small proportion of the overall diet, realtive to woody matter (Atkinson 1995; Hall-Martin et al. 1982). The contribution of each type of plant to the diet varies both seasonally and regionally (Atkinson 1995).

The black rhinoceros select a wide range of plant species according to region and climatic condition (Goddard 1968, 1970; Hall-Martin et al. 1982; Oloo et al., 1994; Atkinson
1995; Muya \& Oguge 2000). The number of food species eaten decreases with increasing aridity. For example, woody browse species increased in number from 74 in the desert of Namibia (Loutit et al. 1987), to 113 species in semi-arid regions like Sinamatella, Hwange National Park in Zimbabwe (Atkinson 1995), and to 191 in the moist Ngorongoro Crater of Tanzania (Goddard 1968). Although a wide range of species are eaten, black rhinoceros are highly selective for both species type and size class (Emslie $\&$ Adcock 1994). Acceptability depends on the level of plant spinescence and the presence of chemical defences (Atkinson 1995). Since a black rhinoceros is a hind-gut fermenter, it does not benefit from bacterial detoxification of chemicals after ingestion. Consequently, it has become adapted to 
selecting for subtoxic levels of phytochemicals by selection from a diversity of food species (Muya \& Oguge 2000). Although the rhinoceros can be highly selective for a few food species and plant sizes (Emslie \& Adcock 1994), the species has the ability to feed on a variety of plants, at least in small quantities (Oloo et al. 1994).

Monro (1982) asserted that tame animals have similar food habits to those of their wild counter-parts. However, Monro did not distinguish between wild captured and tamed adult animals or young hand-raised animals. Atkinson (1995) found that wild captured and captive adult and subadult black rhinos had similar food preferences to those shown by their wild free-ranging counter-parts. Thus, the role of domestication in determining food selection is not clear from the literature. This paper aims at studying the influence of hand raising on diet selection by rhinoceroses. It is important to identify species of plants that are important in the diet of the animals in order to improve their management in bomas and to assess suitability of habitats for reintroduction purposes in the park.

\section{Methods}

\section{Research design}

Matusadona National Park stretches from $28^{\circ} 23^{\prime} \mathrm{E}$ to $28^{\circ} 51$ 'E and from $16^{\circ} 41$ 'S to $17^{\circ} 13^{\prime} \mathrm{S}$. The park is about $1407 \mathrm{~km}^{2}$ in area. An escarpment divides the park into two major geomorphologic landscapes, the semi-arid eutrophic valley floor lying 485-600 m above sea level (a.s.l.) and the wet dystrophic rugged highland section lying 600-1200 m a.s.l. The lowland area is dominated by semi-arid vegetation, mainly Colophosperemum mopane woodland while the highland area supports Brachystegia-Julbernadia woodlands. The study was restricted to the valley floor section of the park.

Three rhinoceros groups were used to study food selection. The groups were: wild, hand-raised, and boma-adapted rhinos. Hand-raised rhinos were animals that had been raised by man and then released into the wild. The hand-raised sample comprised two adults (a male and female) and two subadults (a male and female). Two of these hand-raised rhinos, an adult male and a subadult female, were collared.
Boma-adapted rhinoceroses are defined as animals under semi-captive conditions, where they are kept in bomas (enclosures or kraals) every night. Two males and three females, aged between two and four years represented this group. They were herded during the day to browse within a 3-4 km radius of the bomas, and were also fed known quantities of locally collected browse species over-night in the bomas. In addition, they received supplementary artificial feed in the form of horse cubes.

Habitat classification was based on Taylor (1985) who identified seven overall vegetation types. A modification was done to the vegetation classification because the scrub savanna and mixed escarpment ecotone were not easy to define on the ground. The scrub savanna was placed together with the Colophospermum mopane vegetation, and the mixed escarpment ecotone woodland was grouped together with the Colophospermum-Terminalia woodland. In this study, the term 'thicket' excludes riverine thickets, which were grouped with riverine woodland as riverine habitats. The lakeshore grassland was excluded because it was not considered important for woody plant browsing. Five vegetation types were identified for browse selection studies; Colophospermum-Terminalia-Combretum woodland, riverine, thickets, Combretum woodland and mopane vegetation types.

The study was limited to assessment of browse quantity due to time constraints. A more comprehensive analysis of food selection would require assessment of both quality and quantity.

Information was collected between December 1999 and July 2000 inclusively. Two seasons, the wet season (December-March) and the early dry season (May-July) were used for data collection. The late dry season (August-early November) was not studied because of time constraints. Data were collected only during the day.

\section{Measurement of browse utilisation and determination of principal food species (PFS)}

An indirect observation method, involving measurement of previously browsed vegetation was used for both wild and hand-raised groups. Two hand-raised rhinoceroses were radio-tracked and located to study their food habits. The uncollared hand-raised rhinoceroses were spoor-tracked and positively identified to confirm their hand-raised status, before information was collected.

The indirect method was chosen for reasons highlighted by Kotze \& Zacharias (1993), including the fact that free-ranging animals are not easy to locate, that detection of the observer may influence feeding 
behaviour, that black rhinoceroses are partly nocturnal, and that vegetation may obscure feeding animals. A random search was made for fresh spoor from which to track wild rhinoceroses. The actual procedure to collect data was the same as for the direct method described below.

A direct observation method was used for bomaadapted rhinoceroses when they were being herded during the day. The same method was also used with hand-raised animals when they did not run away from the researcher.

A feeding station (quadrat) was defined as a 5-m radius circle, with a browsed plant species as its centre, along the feeding path. The centre of the quadrat was at the base of the first plant that was identified as browsed. All plants that were browsed within the quadrat were considered part of the same feeding station. In each quadrat, the following variables were recorded: habitat type, the plant species selected, the number of fresh bites taken per plant species, and height of the plant. A 'bite' was defined as any isolated cut twig or branch; where multiple twigs had been bitten, the definition included all twigs less than five millimetres in diameter and within a hypothetical circle with a diameter of five centimetres (HallMartin et al. 1982). To a certain extent, feeding by other browsers could be excluded because black rhinoceroses feed in a characteristic manner. They prune large twigs (Joubert \& Eloff 1971), severing them at a $30-45^{\circ}$ angle (Atkinson 1995).

Plant heights were assigned to height classes.

$$
\begin{aligned}
& \mathrm{A}>1 \mathrm{~m}, \\
& \mathrm{~B}>1 \mathrm{~m} \text { and }<2 \mathrm{~m}, \\
& \mathrm{C}>2 \mathrm{~m} \text { and }<2.5 \mathrm{~m}, \text { and } \\
& \mathrm{D}<2.5 \mathrm{~m}
\end{aligned}
$$

The cut-off point of $2.5 \mathrm{~m}$ in Classes C \& D was chosen because it was assumed that no feeding would take place above $2.5 \mathrm{~m}$ from the ground.

Other information collected at the feeding site was the presence or absence of grazing by rhino and forb browsing. Grazing was defined as the actually eating of grass and sedges by rhinos. This allowed a level of herb eating to be defined as the total number of quadrats in which herbs were recorded divided by the total number of quadrats sampled for a given rhino group.

The proportional usage (proportion of bites taken) for a given plant species, $p_{u}$, is given by the number of bites taken from that species divided by the total number of bites taken from all species in that habitat for a given rhino group. For each habitat type, and for each rhino group, $p_{u}$ values were calculated. The relative percentages of bites on woody plants in each vegetation type by a given rhino group by season, were shown graphically.
A Principal Food Species (PFS) is defined as that food species consumed in greatest quantities irrespective of its availability or proportional abundance (Petrides 1975). PFS represent species that are eaten most by rhinos. In this study a PFS had a $p_{u}$ equal or more than 0.1 .

Chi-square tests were used to analyse the differences in grazing frequencies between different rhino groups. The same tests were used to analyse the total number of bites on woody plants in different vegetation types by season. The Chi-square tests were also used to analyse the number of bites taken on woody species common to rhinoceros groups.

\section{Measurement of browse availability.}

Animals were tracked until a feeding site was encountered. At every fifth quadrat along the feeding path, and only where a woody plant species had been eaten, browse plants (together with other species present within a 5-m radius of the browsed species), were recorded. The fifth quadrat where only grass, sedge and young forb material was consumed was not used to collect data on availability because this aspect of the study was limited to woody browse selection.

All woody plants in the fifth quadrat were recorded and identified. Every fifth quadrat was equivalent to an availability plot. Woody plants were classified by height as described in the above section. Plants whose canopies wholly fell above $2.5 \mathrm{~m}$ from the ground were regarded as unavailable to rhinos for feeding and were ignored.

The proportional availability, $p_{a}$, of browse plant species in the foraging path was then calculated by dividing the number of times that a species occurred in all the availability plots by the total of the number of occurrences for all species in that habitat type. The most available woody species were defined as those that had a proportional value of equal or greater than 0.1 .

\section{Measurement of Food Preference Indices (FPI) and determination of food selection}

The FPI of each woody species, whose browseable material fell whithin the $2.5 \mathrm{~m}$ zone from the ground, is defined as the proportional utilisation of that species divided by its proportional availability (Petrides 1975), i.e. FPI $=p_{u} / p_{a}$. A preferred or selected species is proportionally more frequent in the diet than it is available to an animal. A rejected species occurs in the diet in a lower proportion than it occurs in the habitat (Emslie \& Adcock 1994). A comparative study on the influence of woody plant height on browse selection by hand-raised, boma and 
wild rhinos (Matipano in prep.) was delibarately made subject of another paper.

\section{Results}

\section{Diet Composition}

The numbers of quadrats in which eating of herbs (grasses, sedges and young forbs) and browsing by hand-raised, wild and bomaadapted rhino groups were recorded by season are shown in Table 1. The frequency of browsing was higher than for herb eating for all rhino group by season. Both wild and boma-adapted rhinos selected more herb matter in the wet season than in the early dry season but this trend was reversed for handraised rhinos. In the wet season wild rhinoceros ate the highest overall proportion (20.4 $\%$ ) of herbs while hand-raised rhinos ate the least proportion $(12.9 \%)$. In the early dry season the condition reversed with handraised rhinos eating the highest overall proportion $(27.8 \%)$ of herb matter while wild rhinos ate the least $(7.4 \%)$.

The frequency of woody browsing was above $70 \%$ for all rhino groups in the wet and in the early dry seasons. The highest frequency for woody browsing was over $90 \%$ for the wild group in both seasons, and least $(82.5 \%)$ for boma-adapted rhinos in the wet season and $74 \%$ for the hand-raised group in the early dry season.

The numbers of quadrats in which rhino selected for herbs (grasses, sedges and young forbs combined) and woody species differed significantly among all the three rhino groups $\left(\chi^{2}>36 ; p<0.001 ; d f=2\right.$; Table 2). These differences were also found between pairs of rhino groups $\left(\chi^{2}>4.773 ; p\right.$ $<0.05 ; d f=1)$ except for forbs between wild

Table 1

The frequency of eating herbs (grass, sedge and young forbs) and browsing by different black rhino groups in MNP as expressed by the number of quadrats in which grazing or browsing was recorded (W-Wild; H-Hand-raised ; B-Boma)

\begin{tabular}{lcccccc}
\hline Season & \multicolumn{3}{c}{ Herbs } & \multicolumn{3}{c}{ Woody plants } \\
\hline & & \% No. of quadrats & \% No. of quadrats \\
& W & H & B & W & H & B \\
\hline Wet & 20.4 & 12.9 & 17.5 & 93 & 87.1 & 82.5 \\
Early dry & 7.4 & 27.8 & 13.3 & 98.4 & 74.2 & 86.5 \\
\hline
\end{tabular}

Table 2

Chi-Square tests on the frequency of herbs (grass, sedges and young forbs) and of browsing by different black rhino groups in the wet and early dry seasons, MNP. (Significance level is 0.05; S- significant; Ns-not significant; W-Wild; H-Hand-raised; B-Boma)

\begin{tabular}{lccc}
\hline Season & Rhino groups & \multicolumn{2}{c}{ Comments } \\
& & Herbaceous Plants & Woody Plants \\
\hline Wet season & W vs H vs B & $\mathrm{S}$ & $\mathrm{S}$ \\
& W vs H & $\mathrm{S}$ & $\mathrm{S}$ \\
& W vs B & $\mathrm{S}$ & $\mathrm{S}$ \\
H vs B & $\mathrm{S}$ & $\mathrm{S}$ \\
Early dry & W H vs B & $\mathrm{S}$ & $\mathrm{S}$ \\
season & W vs H & Ns & $\mathrm{S}$ \\
& W vs B & $\mathrm{S}$ & $\mathrm{S}$ \\
& H vs B & $\mathrm{S}$ & $\mathrm{S}$ \\
\hline
\end{tabular}


and hand-raised groups in the early dry season $\left(\chi^{2}=0.067 ; 0.75<p<0.9 ; d f=1\right)$.

\section{Habitat use for herb eating and browsing}

Wild rhinos fed most on herbs in thickets and in riverine habitats in the wet and early dry seasons, respectively (Figs. 1 $\& 2$ ). An example of a grass species that was grazed in wooded vegetation was Panicum maximum. Wild rhinos were not observed feeding on herbs in the lakeshore areas. Hand-raised rhinos fed most on herbs in the lakeshores and mopane in the wet and early dry season respectively. Lakeshore areas were the most important for herb eating for boma-adapted rhinos in both seasons. Examples of plants that were grazed in the lakeshore area included the grass Panicum repens and sedges. Forb browsing included Hibiscus sp. and Sida cordifolia.

The total numbers of bites on woody species in different vegetation types were significantly different among rhino groups for both the wet and in the early dry seasons $\left(\chi^{2}>500, p=0.00, d f=8\right)$. Figures 3 $\& 4$ show that all rhino groups browsed most in the Colophospermum-Terminalia Combretum woodland and thickets in both the wet and early dry seasons. Hand-raised did not browse in the Combretum woodland in the wet season, and boma-adapted rhinos did not browse in the riverine woodland in the early dry seasons. Only boma-adapted rhino browsed in the lakeshore area (not shown on the graphs); fed on young plants like Colophospermum mopane and Acacia sp. seedlings.

Rhino groups adjusted habitat usage for browsing according to season. Wild rhinos used most Colophospermum-TerminaliaCombretum woodland in the wet season and thickets in the early dry season (Figs. 3 \& 4). They browsed least in Combretum woodland and mopane vegetation in both seasons. Wild rhinos increased feeding in thickets and riverine areas in the early dry season compared to the wet season.

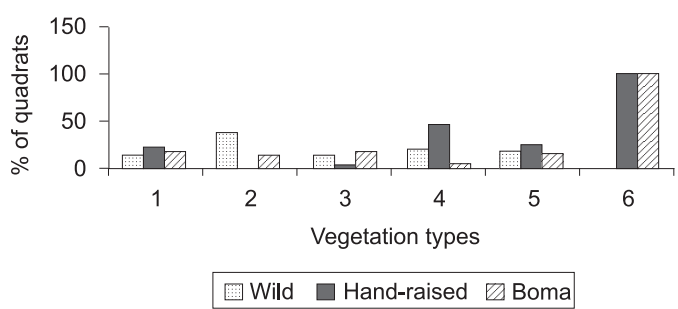

1 - Colophospermum-Terminalia-Combretum woodland

2 - Thickets

3 - Combretum woodland

4 - Riverine vegetation

5 - Mopane vegetation

6 - Lakeshore

Fig. 1. Percentage of quadrats in which grazing by rhino groups was recorded in different vegetation types in the wet season.

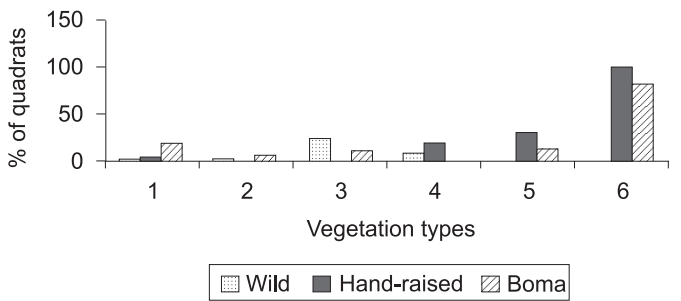

1 - Colophospermum-Terminalia-Combretum woodland

2 - Thichets

3 - Combretum woodland

4 - Riverine vegetation

5 - Mopane vegetation

6 - Lakeshore

Fig. 2. Percentage of quadrats in which grazing by rhino groups was recorded in different vegetation.

Hand-raised rhinos browsed most in Colophospermum-Terminalia-Combretum woodland in both seasons. They browsed least in Combretum woodland in the wet season and least in mopane vegetation in the early dry season. Hand-raised rhinos increased browsing in thickets and Combretum woodland in the early dry season compared to the wet season.

Boma-adapted rhinos browsed most in thickets and least in riverine habitats in both seasons. They increased browsing in Colophospermum- 
Table 3

The numbers of bites on woody species common to rhino groups in different habitats in the wet season (W-wild; H-Hand-raised; B-Boma)

Colophospermum-Terminalia-Combretum habitat Thicket vegetation

\begin{tabular}{|c|c|c|c|c|c|c|c|}
\hline \multirow[t]{2}{*}{ Species } & \multicolumn{3}{|c|}{ Rhino Group } & \multirow[t]{2}{*}{ Species } & \multicolumn{3}{|c|}{ Rhino group } \\
\hline & W & $\mathrm{H}$ & B & & W & $\mathrm{H}$ & B \\
\hline C. zeyheri & 105 & 31 & 88 & C. zeyheri & 10 & - & 102 \\
\hline C. apiculatum & 12 & 71 & 136 & C. apiculatum & - & 9 & 93 \\
\hline K. tettensis & 32 & 23 & 350 & K. tettensis & $185^{\mathrm{a}}$ & $306^{\mathrm{a}}$ & $915^{\mathrm{a}}$ \\
\hline D. quiloensis & 51 & 14 & 26 & D. quiloensis & 11 & - & 15 \\
\hline C. spinosa & 7 & 144 & 36 & C. celastroides & 8 & - & 12 \\
\hline A. nigrescens & 24 & 5 & 15 & T. stuhlmannii & - & 26 & 11 \\
\hline C. pubscens & 24 & 8 & 37 & B. massiensis & 10 & 12 & 6 \\
\hline C. celastroides & - & 11 & 12 & B. massaiensis & 19 & - & 6 \\
\hline
\end{tabular}

Combretum woodlands

\begin{tabular}{|c|c|c|c|c|c|c|c|}
\hline \multirow[t]{2}{*}{ Species } & \multicolumn{3}{|c|}{ Rhino Group } & \multirow[t]{2}{*}{ Species } & \multicolumn{3}{|c|}{ Rhino group } \\
\hline & W & $\mathrm{H}$ & B & & W & $\mathrm{H}$ & B \\
\hline K. tettensis & 59 & - & 142 & D. ceneria & 9 & 6 & - \\
\hline D. condylocarpon & 6 & - & 14 & & & & \\
\hline
\end{tabular}

Mopane vegetation

\begin{tabular}{lccc}
\hline Species & \multicolumn{3}{c}{ Rhino Group } \\
& W & H & B \\
\hline C. mopane & 13 & - & 40 \\
K. tettensis & 11 & - & 25 \\
C. gratissimus & - & 28 & 12 \\
T. stuhlmannii & - & 26 & 6 \\
C. apiculatum & - & 36 & 14 \\
\hline
\end{tabular}

a Species qualifying as PFS and are common to two or all rhino groups.

Terminalia-Combretum woodland in the early dry season compared to the wet season. The boma-adapted rhino group showed the least flexible and the wild group the most flexible pattern of habitat use for browsing with season.

\section{Woody browse Utilisation and Principal Food Species (PFS)}

All rhino groups utilised 87 and 68 woody browse species in the wet and early dry seasons, respectively. Rhino groups shared a few woody browse species within different habitats both in the wet (Table 3 ) and early dry seasons (Table 4).
Differences in the levels of browsing on common woody species were tested between rhino groups for the wet season (Table 5) and for the early dry season (Table 6). All rhino groups fed on most of the common woody browse species at different level of selection in both seasons $\left(\chi^{2}>8 ; p<0.005, d f=2\right)$, except for Baphia massaiensis in thickets in the wet season, which showed no difference in levels of selection between groups $\left(\chi^{2}=2.489 ; 0.05<p<0.1 ; d f=1\right)$.

In most cases, any pair of tested rhino group was shown to select differently for common woody species $\left(\chi^{2}>3.956 ; p<0.05 ; d f=1\right)$. However, the level of feeding by wild and hand-raised rhino groups did not differ sig- 
Table 4

The number of bites on woody species common to rhino groups in different habitats in the early dry season (W-wild; H-hand-raised; B-boma)

Colophospermum-Terminalia-Combretum habitat Thicket vegetation

\begin{tabular}{|c|c|c|c|c|c|c|c|}
\hline \multirow[t]{2}{*}{ Species } & \multicolumn{3}{|c|}{ Rhino Group } & \multirow[t]{2}{*}{ Species } & \multicolumn{3}{|c|}{ Rhino group } \\
\hline & $\mathrm{W}$ & $\mathrm{H}$ & B & & W & $\mathrm{H}$ & $\mathrm{B}$ \\
\hline C. zeyheri & 20 & 21 & 283 & C. zeyheri & 7 & 50 & 129 \\
\hline C. apiculatum & $57^{\mathrm{a}}$ & $207^{a}$ & $383^{a}$ & C. apiculatum & - & 10 & 162 \\
\hline K. tettensis & 6 & 6 & 182 & K. tettensis & $205^{\mathrm{a}}$ & $337^{\mathrm{a}}$ & $930^{\mathrm{a}}$ \\
\hline D. quiloensis & 168 & 48 & 10 & D. quiloensis & $80^{\mathrm{a}}$ & $12^{\mathrm{a}}$ & 14 \\
\hline C. spinosa & $66^{a}$ & $270^{\mathrm{a}}$ & 6 & B. massaiensis & 24 & 85 & 63 \\
\hline S. spinosa & 7 & 58 & - & S. trichoclada & $67^{\mathrm{a}}$ & $110^{\mathrm{a}}$ & - \\
\hline C. pubscens & 8 & 10 & - & T. stuhlmannii & - & 28 & 25 \\
\hline
\end{tabular}

Combretum woodlands

\begin{tabular}{lccc}
\hline Species & \multicolumn{3}{c}{ Rhino Group } \\
& W & H & B \\
\hline C. zeyheri & 7 & 21 & 60 \\
C. apiculatum & 6 & 207 & 41 \\
K. tettensis & - & $6^{\mathrm{a}}$ & $82^{\mathrm{a}}$ \\
C. celastroides & - & 7 & 17
\end{tabular}

Riverine vegetation

\begin{tabular}{lccc} 
Species & \multicolumn{3}{c}{ Rhino group } \\
& W & H & B \\
\hline D. quiloensis & 124 & 45 & - \\
S. kunthianum & 18 & 8 & - \\
B. massaiensis & 66 & 48 & -
\end{tabular}

Mopane vegetation

\begin{tabular}{lccc}
\hline Species & \multicolumn{3}{c}{ Rhino group } \\
& W & H & B \\
\hline C. apiculatum & - & $7^{\mathrm{a}}$ & $54^{\mathrm{a}}$ \\
D. quiloensis & $78^{\mathrm{a}}$ & $30^{\mathrm{a}}$ & -
\end{tabular}

a Species qualifying as PFS and are common to two or all rhino groups

nificantly for the following: Karomia tettensis in Colophospermum-Terminalia-Combretum woodland vegetation, Baphia massaiensis in thickets, and Dichrostachys ceneria in riverine habitat in the wet season $\left(\chi^{2}<2.91\right.$; $p>0.05 ; d f=1$; Table 5). These rhino groups did not differ significantly on their feeding on Combretum zeyheri, $K$. tettensis, Carphalea pubescens in ColophospermumTerminalia-Combretum woodland and on $B$. massaiensis in Combretum woodland in the early dry season $\left(\chi^{2}<2.25 ; d f=1\right.$; Table 6).

Wild and boma-adapted rhino groups had no significant differences when feeding on $C$. zeyheri, A. nigrescens and $C$. pubescens in Colophospermum-Terminalia-Combretum woodland vegetation, and on $D$. quiloensis, B. massaiensis and Combretum celastroides in thickets in the wet season $\left(\chi^{2}<1.509\right.$; $p>0.05 ; d f=1$; Table 5). The feeding behaviour was completely different between the wild and boma-adapted rhinos in the early dry season (Table 6).

Hand-raised and boma-adapted rhino groups did not differ significantly in their feeding levels on Combretum celastroides in Colophospermum-Terminalia-Combretum woodland and on Baphia massaiensis in thickets in the wet season $\left(\chi^{2}<1.09\right.$; $p>0.05 ; d f=1$; Table 5). These rhino groups did not differ significantly on their feeding on Terminalia stuhlmannii in Colophospermum-Terminalia-Combretum woodland and on Diospyros quiloensis and B. massaiensis in thickets in the early dry season $\left(\chi^{2}<2.25\right.$; 
Table 5

Chi-Square Tests on the number of bites on woody species common for black rhinos groups in different habitats in the wet season (Significant level is 0.05; W-Wild; H-Hand-raised; B-Boma rhinos)

\begin{tabular}{|c|c|c|c|}
\hline Habitat Type & Species & Rhino Group & $\begin{array}{c}\text { Significant (s)/ } \\
\text { Not significant }(\mathrm{Ns})\end{array}$ \\
\hline \multirow[t]{9}{*}{$\begin{array}{l}\text { Colophospermum-Terminalia- } \\
\text { Combretum woodland }\end{array}$} & C. zeyheri & $\begin{array}{c}\text { W vs } \mathrm{H} \text { vs } \mathrm{B} \\
\mathrm{W} \text { vs } \mathrm{H} \\
\mathrm{W} \text { vs } \mathrm{B} \\
\mathrm{H} \text { vs } \mathrm{B}\end{array}$ & $\begin{array}{c}\text { S } \\
\text { S } \\
\text { Ns } \\
\text { S }\end{array}$ \\
\hline & C. apiculatum & $\begin{array}{c}\text { W vs H vs B } \\
\text { W vs H } \\
\text { W vs B } \\
\text { Hvs B }\end{array}$ & $\begin{array}{l}\mathrm{S} \\
\mathrm{S} \\
\mathrm{S} \\
\mathrm{S}\end{array}$ \\
\hline & K. tettensis & $\begin{array}{c}\text { W vs } H \text { vs } B \\
\text { W vs } H \\
\text { W vs } B \\
H \text { vs } B\end{array}$ & $\begin{array}{l}\mathrm{S} \\
\mathrm{Ns} \\
\mathrm{S} \\
\mathrm{S}\end{array}$ \\
\hline & D. quiloensis & $\begin{array}{l}\text { W vs } H \text { vs } B \\
\text { W vs } H \\
\text { W vs B } \\
H \text { vs B }\end{array}$ & $\begin{array}{l}\mathrm{S} \\
\mathrm{S} \\
\mathrm{S} \\
\mathrm{S}\end{array}$ \\
\hline & C. spinosa & $\begin{array}{c}\text { W vs } \mathrm{H} \text { vs } \mathrm{B} \\
\mathrm{W} \text { vs } \mathrm{H} \\
\mathrm{W} \text { vs } \mathrm{B} \\
\mathrm{H} \text { vs } \mathrm{B}\end{array}$ & $\begin{array}{l}\mathrm{S} \\
\mathrm{S} \\
\mathrm{S} \\
\mathrm{S}\end{array}$ \\
\hline & A nigrescens & $\begin{array}{c}\text { W vs } \mathrm{H} \text { vs B } \\
\text { W vs } \mathrm{H} \\
\text { W vs B } \\
\mathrm{H} \text { vs B }\end{array}$ & $\begin{array}{c}\text { S } \\
\text { S } \\
\text { Ns } \\
\text { S }\end{array}$ \\
\hline & C. pubescens & $\begin{array}{c}\text { W vs } H \text { vs } B \\
\text { W vs } H \\
\text { W vs } B \\
H \text { vs } B\end{array}$ & $\begin{array}{l}\mathrm{S} \\
\mathrm{S} \\
\mathrm{NS} \\
\mathrm{S}\end{array}$ \\
\hline & C. celastroides & $\mathrm{H}$ vs $\mathrm{B}$ & Ns \\
\hline & B. massaiensis & W vs B & $\mathrm{S}$ \\
\hline \multirow[t]{7}{*}{ Thickets } & K. tettensis & $\begin{array}{l}\text { W vs } H \text { vs } B \\
\text { W vs } H \\
\text { W vs } B \\
H \text { vs } B\end{array}$ & $\begin{array}{l}\mathrm{S} \\
\mathrm{S} \\
\mathrm{S} \\
\mathrm{S}\end{array}$ \\
\hline & B. massaiensis & $\begin{array}{l}\text { W vs } H \text { vs } B \\
\text { W vs } H \\
\text { W vs B } \\
H \text { vs B }\end{array}$ & $\begin{array}{l}\text { Ns } \\
\text { Ns } \\
\text { Ns } \\
\text { Ns }\end{array}$ \\
\hline & D. quiloensis & W vs B & Ns \\
\hline & C. zeyheri & W vs B & S \\
\hline & C. apiculatum & $\mathrm{H}$ vs $\mathrm{B}$ & S \\
\hline & T. stulhmannii & $\mathrm{H}$ vs $\mathrm{B}$ & S \\
\hline & C. celastroides & W vs B & $\mathrm{Ns}$ \\
\hline Combretum woodland & K. tettensis & W vs B & $\mathrm{S}$ \\
\hline Riverine vegetation & $\begin{array}{l}\text { D. ceneria } \\
\text { D. condylocarpon } \\
\text { C. mopane } \\
\text { K. tettensis }\end{array}$ & $\begin{array}{l}W \text { vs } B \\
W \text { vs } B \\
W \text { vs } B \\
W \text { vs } B\end{array}$ & $\begin{array}{l}\mathrm{Ns} \\
\mathrm{S} \\
\mathrm{S} \\
\mathrm{S}\end{array}$ \\
\hline Mopane & $\begin{array}{l}\text { C. gratissimus } \\
\text { T. stuhlmannii } \\
\text { C. apiculatum }\end{array}$ & $\begin{array}{l}H \text { vs } B \\
H \text { vs } B \\
H \text { vs } B\end{array}$ & $\begin{array}{l}\mathrm{S} \\
\mathrm{S} \\
\mathrm{S}\end{array}$ \\
\hline
\end{tabular}




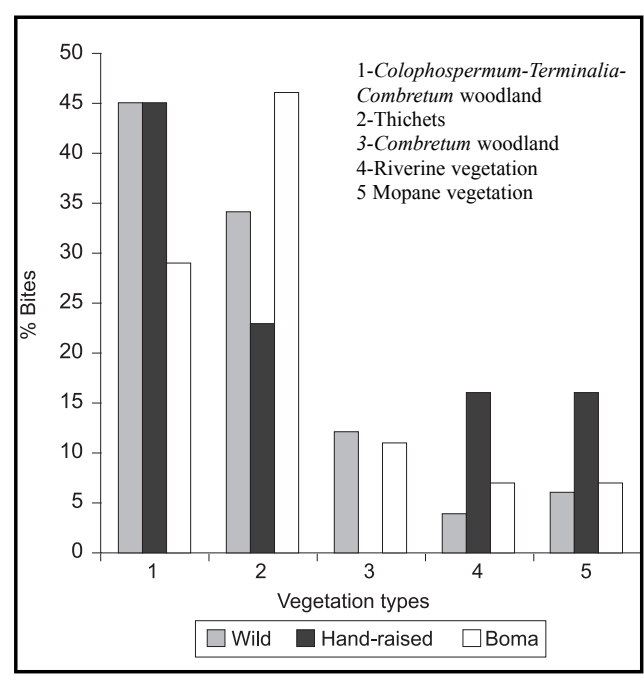

Fig. 3. Percentage of bites on woody plants in different vegetation types by rhino groups in the wet season.

$p>0.05$;

$d f=1$

Table 6).

The most utilised woody plant species for the wet and early dry seasons $\left(p_{u}>0.10\right)$ were ragarded as Principal Food Species (PFS). Rhino groups shared a few common PFS including $K$. tettensis in thicket vegetation in the wet season and early dry season (Tables 3 \& 4) and Combretum apiculatum in Colophospermum-Terminalia-Combretum woodland in the early dry season (Table 4). Hand-raised and wild groups shared the following additional PFS: Catunaregan spinosa in Colophospermum-Terminalia-Combretum woodland, $D$. duiloensis in mopane vegetation and thickets, and S. trichoclada in thickets. Hand-raised and boma-adapted rhinos shared the following additional PFS: $K$. tettensis in Combretum woodland and $C$. apiculatum in mopane.

Some species that registered as PFS in the lower height categories were not in the D height class. For example, Acacia nigrescens, Carphalea pubscens and Baphia massaiensis were utilised at levels ranging between $11 \%$ and $13 \%$ in the lower height categories $(<1 \mathrm{~m}$ height $)$ but were utilised at lower lev-

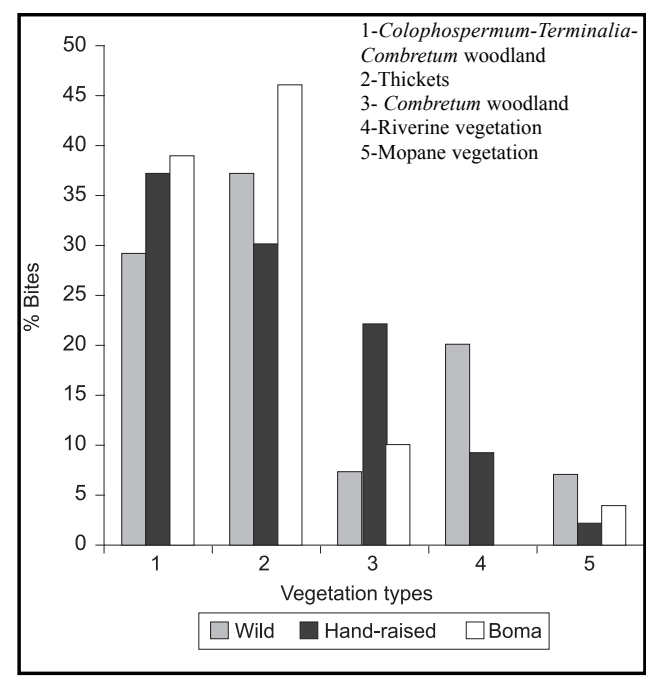

Fig. 4. Percentage of bites on woody plant species in different vegetation type by rhino groups in the early dry season.

els (from $6 \%$ to $8 \%$ ) in the D height class. This was for the Colophospermum-Terminalia-Combretum woodland.

\section{Woody browse preference and selection}

All rhino groups preferred totals of 85 and 70 woody species in the wet and early dry seasons, respectively. The FPIs were expressed with species-size. Many of the species preferred by one group received low FPI scores for another; thus there was little similarities in preferences between groups in a given vegetation type.

Some species were highly selected or highly preferred in the lower height categories, but rejected in the D height class. Examples of such species were Bauhinia tomentosa and Baphia massaiensis which had preference indices of 1.465 and 4.421 in the lower height categories, compared to indices of 0.991 and 0.892 in the D height class, respectively, in the ColophospermumTerminalia-Combretum vegetation and in thickets. 
Table 6

Chi-Square Tests on the number of bites on woody species common to black rhino groups in different habitats in the early dry season in MNP (Significance level is 0.05; W-Wild rhinos; H-Hand-raised rhinos; B-Boma rhinos)

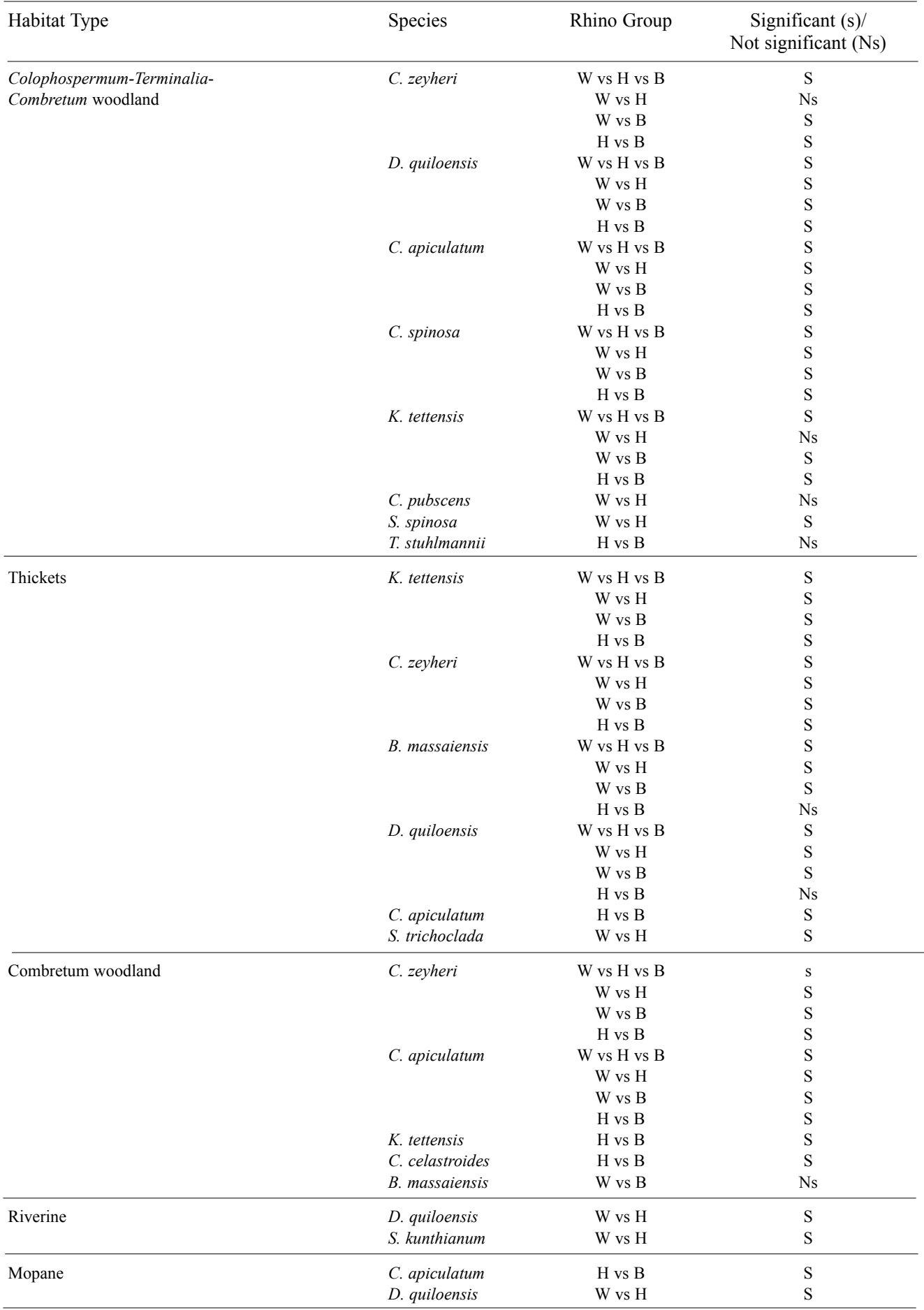




\section{Discussion and conclusion}

\section{Summary of group differences}

Patterns of habitat use for grazing and for browsing were different for all rhino groups. In general, the three rhino groups shared different feeding behaviours for the same habitat according to season:

- the percentages of browsing and grazing were different,

- food species selected differed, or

- a narrow range of species was shared, or

- the number of bites on shared species differed, and

- the preference indices on common species differed

Hand-raised rhinos avoided using Combretum woodlands in the wet season, could not make a selection of food species in thickets in the early dry season. Thickets are important dry season habitats for wild rhinos (Atkinson 1995). Hand-raised rhinos selected some species like Erythroxylum zambesiacum and Cauboura glauca that are not normally favoured by rhinos. Boma and handraised rhinos selected for Colophospermum mopane and Euclea divinorum in the wet season. Wild rhino preferred Euclea divinorum during the dry season (Atkinson 1995).

Hand-raised and boma-adapted rhinos showed anomalous feeding behaviour. A male hand-raised animal was observed feeding on impala carcass (Woodfine pers. comm.). Plastic material was recorded in the dung of the same rhino, which could indicate anomalous feeding behaviour. On Imire Game Ranch, hand-raised rhinos licked animal carcass and bones (Poole 1995). This might mean that hand-raised rhinos were failing to obtain a diet with adequate minerals and they resorted to eating bones. Bones provide minerals, including calcium.

\section{Explaining differences in feeding behaviour}

Many factors affect dietary selection, including season, resource distribution (Atkinson 1995; Pellew 1984), plant phenology and size, and the management history of the animal. All rhino groups changed their home ranges spatially and in turn adjusted habitat use (Matipano 2000), resulting in differing food utilisation and especially selection with season within habitats. However, the nature of this adjustment differed for each group.

Oloo et al. (1994) highlighted reasons for this seasonal variability in food species in the diet. In this study, seasonal requirement for succulence (high-moisture food) could have been a major factor governing diet selection; choice of riverine habitats in the dry season would have exposed wild rhinos to a 'new' range of plant species from which to select. Riverine vegetation has a higher moisture content providing more 'green bite' during the dry season. Herding restricted the movement of boma-adapted rhinos such that they could not use riverine areas in the early dry. Herding of boma-adapted rhinos partly explained dietary differences between them and wild rhinos.

Secondly, rhinos changed browse selection in response to browse phenological changes. Reduced palatability of browse in the dry season will induce a shift to more palatable species, as well as to other plant parts of the same species (Atkinson 1995). The valley floor is semi-arid and most species are deciduous. As drier conditions prevail, evergreen species contribute more to the diet than deciduous species (Atkinson 1995). Species like Cleistochlamys kirkii were eaten by wild rhinos, and Euphorbia sp. and Euclea divinorum by hand-raised and boma-adapted rhinos in the early dry season. Some species that dropped leaves later in the dry season like Strychnos spinosa, Strychnos madagascariensis, Catunaregan spinosa and Diospyros quiloensis were favoured in the early dry season. In this study, hand-raised rhinos took stems (ca $15 \mathrm{~mm}$ diameter) from Strychnos spinosa in the early dry season. In this study, the quality of food eaten was not measured. Thus, it was not possible to confirm the observation of Hall-Martin et al. (1982) that black rhinos modified their diet to suit environmental conditions by reducing the intake of high fibre plants in favour of more succu- 
lent and nutritive species. However, plant phenology might have influenced diet selection through change in quality. Browse quality is influenced by toxic phytochemical and nutrient content in plants.

Plant height was another factor influencing selection. Some shrub species, only appeared as PFSs or were selected in the lower height classes and not in the D height class. Examples were the shrubs such as Dichrostachys ceneria and Carphalea pubscens in Colophospermum-Terminalia-Combretum vegetation, Holarrhena pubescens and Croton gratissimus in thickets. Black rhinos feed mostly on those plants within the $50-120 \mathrm{~cm}$ height category from the ground (OwenSmith 1988). Individual plants $<20 \mathrm{~cm}$ in height were included in the study to determine availability. This inclusion probably resulted in underestimating preference for those species that were most used when above $20 \mathrm{~cm}$ in height.

In this study boma and hand-raised rhinos selected for more species than the wild group. Other studies have shown a high number of food species for wild black rhino (Goddard 1970; Hall-Martin et al. 1982; Oloo et al.; 1994; Atkinson 1995). In this study, all species that could be utilised were not measured since data for the late dry season were not collected. Further, some plant species were only recorded as utilised and preferred, but as not available. This means that such species could have been highly sought for and selected, e.g. Euphorbia spp. Alternatively, these were rare species only taken by chance, and were not of any dietary importance, e.g. Crossopteryx febrifuga and Manilkara mochisa in Combretum woodlands, Bridelia carthertica, Pterocarpus brenanii and Combretum collinum in Mopane in the case of boma-adapted rhinos. A third explanation is simply that sampling effort was too low to provide meaningful data for spatially scattered species.

The distribution of food resources is not the same for a given habitat type. Individual rhinos probably perceive resource patchiness differently based on management history, which modifies feeding behaviour. It is likely that the boma group fed on most of the food patches encountered. The reasons for this are that animals:

- were restricted to the same small feeding ground;

- had limited nocturnal feeding in bomas, and could have been permanently hungry. They fed for longer time in the afternoons than the wild group, probably to compensate for the time they are put in bomas before sunset (Poole 1995);

- had reduced ability to select food because of some reliance on supplementary feed;

- browsed in a group, whereby the feeding of one rhino encouraged that of adjacent animal. This would account for the high intensity of feeding by boma animals, both in terms of the number of species per station and in terms of the number of bites per plant; and

- after weaned young calves are stressed and hungry, and may feed on poisonous plants (Tyler 1999 pers. comm.).

Wild rhinos select highly for a few species (Emslie \& Adcock 1994) and feed in a spatially uneven manner (Kotze \& Zacharias 1992). This study, showed that boma-adapted rhinos were less selective for browse species than either hand-raised or wild rhino group. Boma-adapted rhinos, and to an extent the hand-raised group, apparently browsed at sites closer to each other and took more bites per feeding station than wild rhinos. However, this feeding behaviour was to a large extent imposed upon the boma group, because they were restricted to certain habitats by herding. For hand-raised rhinos, the feeding behaviour was influenced by the habit of restricting home ranges close to human settlement (Matipano 2000).

Black rhinos have high dietary selection for a few species and high dietary diversity by taking other species at lower preferences. This feeding strategy can be explained by the need to obtain the full complement of food quality requirements, and at the same time limit the amount of each species taken at one time in order to keep intoxication tolerable 
(Emslie \& Adcock 1994; Muya \& Oguge 2000). However, this does not adequately explain the higher diversity of food species selected by both boma and hand-raised rhinos. One speculative explanation is that, having been exposed initially to a narrower range of browse species, these groups could have been used to relatively higher levels of phytotoxic chemicals, and could perhaps tolerate feeding for longer on a single species, as well as on a wider range of species encountered. This reduced selectivity is also shown by hand-raised rhinos which settled in the vicinity of human settlement, where they were exposed to human litter. Plastic material was recorded in the dung of such rhinos, which could indicate reduced selective capacity.

A second explanation is that rhinos reduce the number of bites per plant with the increasing times of feeding on the same species by day (Poole 1995). The boma group, therefore, ingested only small amounts from the narrow range of species they were given in bomas overnight and relied on artificial feed. Hand-raised rhinos at Imire most preferred cubes to other food items in both the wet and dry seasons (Poole 1995). Horse cubes, compared with natural browse were easily digested and rhinos may be feeding on more species simply to obtain roughage. Boma-adapted rhinos did not show signs of poor body condition. There might have been an associative effect of foods. The supplements might have improved the efficiency of utilising of browse.

Wild rhinos might have eaten a relatively low diversity of food species as a strategy to reduce the intake of toxins. Bias in data collection might be an alternative reason for recording a low diversity of browse species taken by wild rhinos. It was difficult to locate and follow tracks for reasonable distances, compared to the ease of direct observation on boma-adapted rhinos, and radio tracking of hand-raised rhinos. In addition, lists of plants utilised were probably incomplete because studies using more than one technique yield longer lists (Muya \& Oguge 2000).

These investigations on selected aspects of the behavioural ecology of hand-raised rhinos were seasonally biased. The late dry season studies, especially on preference, were not carried out due to time constraints. Further, studies were limited to daytime, ignoring nocturnal activities of rhinos. The results obtained were not representative of the annual requirements for rhinos. If a home range shifted, available habitats would also change, together with available browse species. Monitoring or studying animals during periods of resource scarcity is vital to provide knowledge on the ecology and management of rhinos.

The method used to collect data ensured that it was the rhino not the researcher determining availability of browse and that plants included were within the reach of a rhino (Atkinson 1995). This made it possible to study availability and utilisation at the same time. However, with appropriately designed studies, separate utilisation and availability studies can be done (Du Toit pers. comm.). $\mathrm{Du}$ Toit's proposal would be done with the assumption that the researcher can determine feeding sites in a manner equivalent to that of a rhino. The problem with this proposed approach is that any differences between the perception of browse availability by the researcher and the rhinos would not be established.

\section{Conclusions}

In this study, semi-tamed hand-raised rhinos had different and anomalous feeding behaviour, compared to wild rhinos. Hand-raised rhinos selected fewer browse plant species than boma-adapted rhinos, but more than wild rhinos. However, plant species selection may, in fact, be less important than nutritional levels. Rhinos may take different plants but without significantly affecting nutritional intake. There is, thus, a need for chemical analysis of plants utilised by rhino groups, especially in the dry season when food quality is critical. Information is 
required on levels of toxins, protein, lignin and nutrients, e.g., $\mathrm{Na}, \mathrm{Ca}$ and $\mathrm{Zn}$. Herding boma-adapted rhinos during the day is importatnt as it gives them opportunity to learn about their release environment prior to reintroduction.

The approach at MNP of providing young rhinos with both artificial feed and indigenous browse whilst they are in bomas, and of herding them in the field during the day, allows animals to acquire some necessary information on habitat and food selection for survival in the wild after release. This approach to raising rhinos differs from, and is superior to, complete captive management. Under conditions of total captivity, exposure to natural conditions does not occur. On the other hand, complete freemanagement in conservancies and other larger areas is better than hand-raising.

\section{Acknowledgements}

Financial support from the European Commission is greatly appreciated. I would like to thank Dr. C.A.M. Attwell and Mr. R.F. du Toit for their guidance. I also thank Mr. E. Chidziya of the Department of National Parks and Wildlife Management for his support during the study. I am grateful to E. Muchuchutiti and T. Nyakashaya for their assistance during field work. Finally, I thank the Department of National Parks and Wildlife Management for granting permission to carry out the study in Matusadona National Park.

\section{References}

ATKINSON, S.J. 1995. Maintenance of captive black rhinos (Diceros bicornis) on indigenous browse in Zimbabwe: Energetics, nutrition and implications for conservation. MSc. thesis. University of Zimbabwe.

EMSLIE, H. R. \& K. AdCOCK. 1994. Feeding ecology of the black rhinoceros. Pp. 65-81. In: PENZHORN, B.L. \& N.P.L. KRIEK (eds.). Proceedings of symposium on rhinos as game ranching animals. Onderstepoort. 9-10 September 1994. Wildlife Group of the South African Veterinary Association. Republic of South Africa.

GodDARD, J. 1968. Food preferences of black rhinoceros populations. East African Wildlife Journal 6: 1-18.
GodDARD, J. 1970. Food preferences of black rhino in the Tsavo National Park. East African Wildlife Journal 8: 145-161.

Hall-Martin, A.J., T. Erasmus \& B.P. Botha. 1982. Seasonal variation in the diet and faeces composition of black rhino, Diceros bicornis in Addo Elephant National Park. Koedoe 25: 63-82.

JouberT, E. \& F.C.ELOFF. 1971. Notes on the ecology and behaviour of the black rhinoceros, Diceros bicornis, L. 1758 in South West Africa. Madoqua Ser. 1(3): 5-53.

KotZe, D.C. \& P.J.K. Zacharias. 1993. Utilisation of woody browse and habitat by the black rhino (Diceros bicornis) in western Itala Game Reserve. African Journal of Forest Science 10(1): 36-40.

Loutit, B. D., G.W. Louw \& M.K. Seely. 1987. First approximation of food preferences and the chemical composition of the diet of the desert dwelling Diceros bicornis bicornis L. Madoqua 15: 35-54.

Matipano, G. 2000. Effects of hand raising on balck rhinoceros, Diceros bicornis, L. in Matusadona National Park, Zimbabwe: An evaluation of ranging behaviour, habitat use and browse selection. MSc. thesis, University of Zimbabwe, Harare.

MonRo, R.H. 1982. An appraisal of some techniques to investigate the feeding ecology of large herbivores with reference to study of impala in the Northern Transvaal. African Journal of Ecology 20: 71-80.

Muya, S. M. \& N.O. Oguge. 2000. Effects of browse availability and quality on black rhino (Diceros bicornis michaeli Groves 1967) diet in Nairobi National Park, Kenya. Journal of African Ecology 38(1): 62-71.

Oloo, T.W., R. BRETT \& T.P. Young 1994. Seasonal variation in the feeding ecology of black rhinos (Diceros bicornis L.) in Laikipia, Kenya. African Journal of Ecology 32: 142-157.

Pellew, R. 1984. Food consumption and energy budgets of the giraffe. Journal of Applied Ecology 21: 141-159.

Petrides, G. A. 1975. Principal foods versus preferred foods and their relations to stocking rate and range conditions. Biological Conservation 7: 161-169.

Poole, A. 1995. Feeding ecology of the black rhino, Diceros bicornis in a highveld habitat. BSc. (Hons.) thesis. Bangor University, UK.

TAYLOR, R.D. 1985. The response of buffalo, Syncerus caffer (Sparrman) to the Kariba Lake grassland (Panicum repens L.) in Matusadona National Park. PhD thesis, University of Zimbabwe, Harare. 